\title{
Critical analysis on hydrogen as an alternative to fossil fuels and biofuels for vehicles in Europe
}

\author{
Fernando Hernández Sobrino*, Carlos Rodríguez Monroy, José Luís Hernández Pérez \\ Department of Business Administration, School of Industrial Engineering, Universidad Politécnica de Madrid, José Gutierrez Abascal 2, 28006 Madrid, Spain
}

Keywords:

Hydrogen

Biofuel

Renewable energy

Fuel cell

Automotive industry

\begin{abstract}
A B S T R A C T
In recent times, the global debate on the environment has been centered on $\mathrm{CO}_{2}$ emissions. This gas is the major cause of the "greenhouse effect" and people are more concerned with the idea that the emissions of this gas should be minimized. As a result of this concern, the Kyoto Protocol was enacted and subscribed to by many countries, setting the maximum gas emissions for them.

Fossil fuels are a major source of $\mathrm{CO}_{2}$ emissions. For some years now The European Union has been seeking to promote some years now the use of biofuels as substitutes for diesel or petrol for transport purposes. As a result of this policy, in 2003 the European Union (EU) Directive 2003/30/EC [1] was developed with the aim of promoting the use of biofuels as a substitute for diesel or gasoline among European Union countries as well as to contribute to fulfilling the commitments acquired on climate change, security of supply in environmentally friendly conditions and the promotion of renewable energy sources.

In order to achieve these goals, the directive forces all EU members to ensure that before December 31 of 2010 at least $5.75 \%$ of all gasoline and diesel fuels sold for transport purposes are biofuels. European Union countries have social and economic characteristics unique to themselves. The energy dependence on foreign sources, the features of the agricultural sector or the degree of industrialization varies greatly from one country to another. In this context, it is questionable whether the obligation imposed by this directive is actually achieving in its application uniform and/or identical goals in each of the countries involved and whether the actions of the various governments are also aligned with these goals. All these ideas were developed in a previous report (Sobrino and Monroy (2009) [2]).

This report examines the possibility of using hydrogen as an alternative to fossil fuels and biofuels from a technical, economic and environmental point of view in the specific case of a European Union country: Spain.
\end{abstract}

\section{Contents}

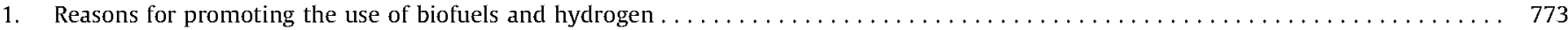

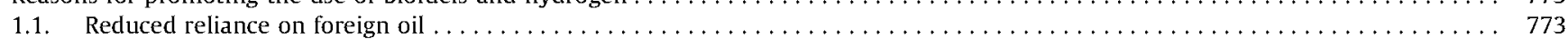

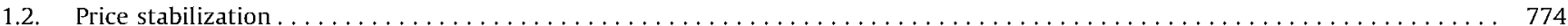

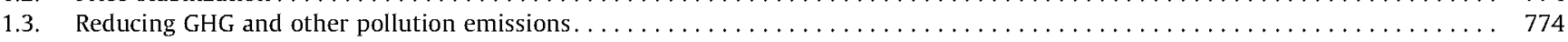

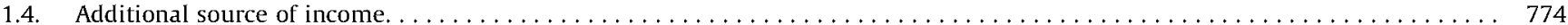

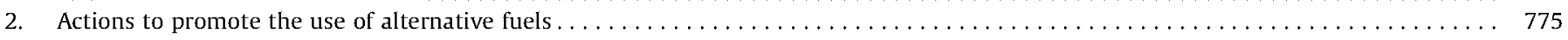

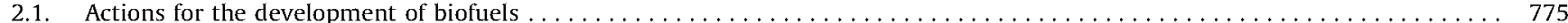

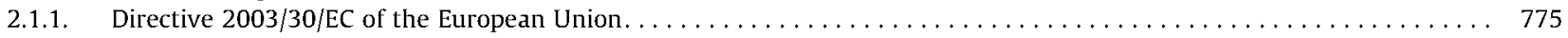

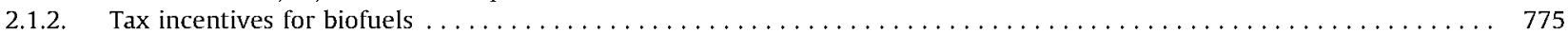

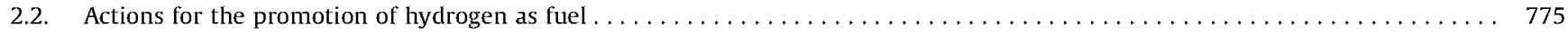

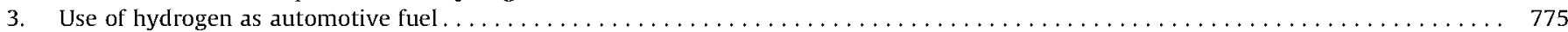

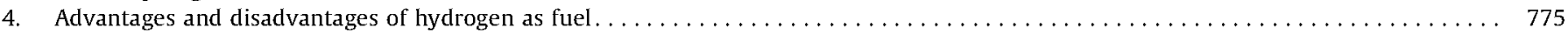

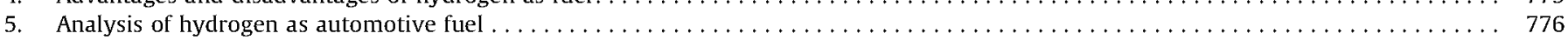

\footnotetext{
* Corresponding author. Tel.: +34915748992.

E-mail addresses: sobrinof@gmail.com (F.H. Sobrino), crmonroy@etsii.upm.es (C.R. Monroy), joseluishernandezperez@gmail.com (J.L.H. Pérez)
} 


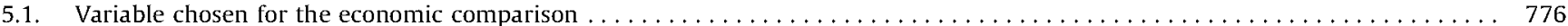

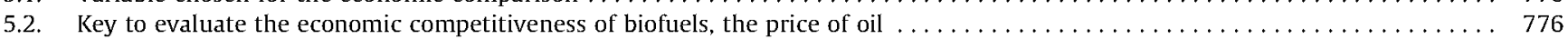

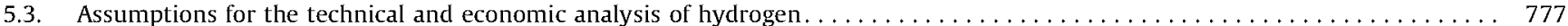

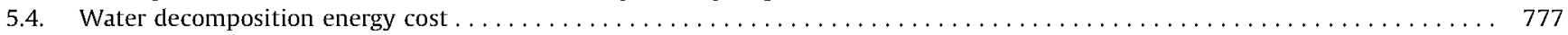

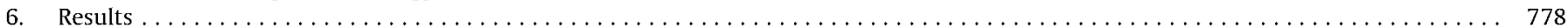

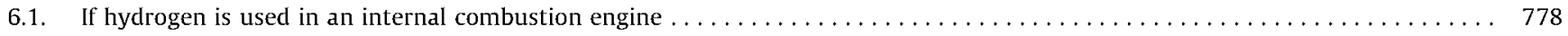

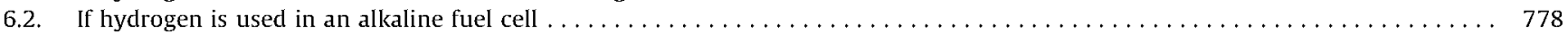

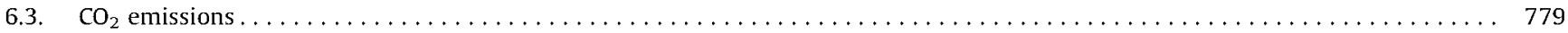

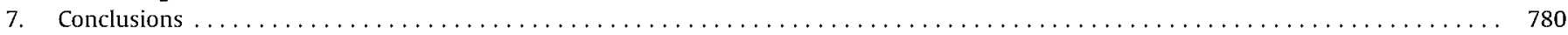

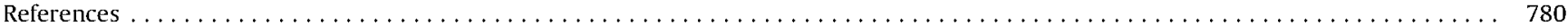

\section{Reasons for promoting the use of biofuels and hydrogen}

Biofuels and hydrogen have characteristics that are beneficial in principle. Their use is advantageous compared to fossil fuels:

- Biofuels and hydrogen may reduce the external energy dependence. They could be produced domestically in the EU, reducing petroleum imports, improving the balance of payments, improving domestic energy security, and reducing the reliance on petroleum from unstable areas of the world.

Biofuels and hydrogen may help to stabilize fossil fuel prices. Petroleum prices are volatile and expected to increase over time. However, biofuels are a backstop technology, potentially constraining the growth in petroleum prices.

Biofuels and hydrogen may help to reduce the emission of greenhouse gases (GHG) and other emissions. Biofuels recycle carbon from the atmosphere and have cleaner emissions, thus reducing GHG emissions and mitigating climate change.

- Biofuels may be an additional source of income for the primary sector. Biofuels are renewable and increase the demand for agricultural commodities, thus potentially boosting agricultural producers' income and prices.

Each of these aspects is further discussed below.

\subsection{Reduced reliance on foreign oil}

Europe is highly dependent on external energy sources. In 2007, the most dependent EU Members were Cyprus (100\%), Portugal (99.4\%), Luxembourg (99\%), Latvia (94\%) and Ireland (90.2\%). The less dependent were United Kingdom (13\%), Poland (18.4\%), Estonia (33.9\%), Czech Republic (37.6\%) and the Netherlands (38.9\%). Denmark is an exception in Europe because it produces more energy than it needs; it is a net energy exporter [3].

Let us analyze the Spanish case. Spain is highly dependent on external energy sources. Table 1 shows its sources of primary energy in 2007.

The only fully domestic primary energy is the renewable power plants (6.95\%). Biofuels represent $0.26 \%$ of the total energy consumed in Spain.

Nuclear power plants represent $9.75 \%$ of primary energy. Official data consider this source as a domestic one. Since 2002 all the fuel used in the nine nuclear power plants existing in Spain is imported [5]. Regarding coal, 56\% was imported in 2005 and this figure grows every year.

Table 1

Spain primary energy sources in 2007 (in thousands of ktoe)

\begin{tabular}{lrr}
\hline Coal & 20,236 & $13.74 \%$ \\
Oil & 70,848 & $48.11 \%$ \\
Methane & 31,602 & $21.46 \%$ \\
Nuclear & 14,360 & $9.75 \%$ \\
Renewable & 10,229 & $6.95 \%$ \\
Total & 147,275 & $100.00 \%$ \\
\hline
\end{tabular}

Source: [4].
Almost all fuel oil and natural gas are imported, so the Spanish self-energy supply is only $22.49 \%$ considering nuclear fuel as domestic. Otherwise, the self-energy supply is $12.74 \%$. These data show that Spain is seriously vulnerable from the energy point of view.

Fossil fuels for vehicles are produced from oil to an extent of almost $100 \%$. Spain imports almost all the oil it consumes and the tendency for self-supply is to decrease (from $0.5 \%$ in 2001 to $0.2 \%$ in 2007) [6]. As a consequence of this energy dependence, Spain suffers from significant trade deficits [7].

A biofuel industry could help the EU to import less petroleum, because producers grow and manufacture the biofuels domestically. This issue has already been studied for the U.S. market [8-12].

In Spain, biofuel consumption (ethanol and biodiesel) has increased from 228 ktoe in 2004 to 382 ktoe in 2007 [13]. The percentage of energy from biofuels over the total energy is small $(0.2 \%$ in 2004 and $0.3 \%$ in 2007) but in the future, if the biofuel and/or hydrogen consumption increases more than the energy consumption, the percentage of imported oil would decline. Table 2 shows the origin of oil imported by Spain.

Importing large quantities of oil especially from certain countries creates the problem that these regions are politically unstable [15].

On the other hand, it is necessary to analyze the origin of the raw material used for obtaining biofuels from plants. Spain is one of the largest producers of those cereals and vegetables that can be used as raw materials for biofuels. Its primary sector is strong.

Table 3 shows data from the 2007-2008 crop campaign which can be used to produce ethanol.

From Table 3, it is deduced:

- Spain is a net importer of cereals.

- Although $4.02 \%$ of cereal production $(1,260,000$ tons $)$ is used to produce ethanol, Spain imports large quantities of cereals:

- $11,874,000$ tons of wheat, barley, maize and sorghum are imported. 8,774,000 tons are from countries that do not belong to the European Union.

$-595,000$ tons of barley are exported and 200,000 tons are used to produce ethanol.

Table 2

Source of oil imported by Spain in 2007 (in thousands tons).

\begin{tabular}{lrr}
\hline Russia & 13,433 & $24.47 \%$ \\
Mexico & 7,180 & $13.08 \%$ \\
Saudi Arabia & 5,468 & $9.96 \%$ \\
Iran & 4,512 & $8.22 \%$ \\
Libya & 4,511 & $8.22 \%$ \\
Nigeria & 4,402 & $8.02 \%$ \\
Iraq & 3,254 & $5.93 \%$ \\
Venezuela & 2,124 & $3.87 \%$ \\
United Kingdom & 722 & $1.32 \%$ \\
Algeria & 395 & $0.72 \%$ \\
Others & 8,886 & $16.19 \%$ \\
Total & 54,887 & $100.00 \%$ \\
\hline Source: $[14]$. & &
\end{tabular}


Table 3

Production and consumption of cereals (thousand tons) 2007-2008 Campaign.

\begin{tabular}{|c|c|c|c|c|c|c|}
\hline & Wheat & Barley & Maize & Sorghum & Other & Total \\
\hline Production & 5036 & 11,161 & 3391 & 155 & 2,440 & 22,183 \\
\hline Raw material to produce ethanol & 60 & 200 & 650 & 350 & 0 & 1,260 \\
\hline Imports & 2324 & 100 & 7000 & 2450 & 228 & 12,102 \\
\hline EU countries & 1500 & 100 & 1500 & 0 & 178 & 3,278 \\
\hline Non-EU countries & 824 & 0 & 5500 & 2450 & 50 & 8,824 \\
\hline Exports & 0 & 595 & 0 & 0 & 230 & 825 \\
\hline
\end{tabular}

Source: [16].

Regarding the raw material for biodiesel production, it is noted that percentages and origins of oils are variable and depend on the prices of different oils and seeds. A typical distribution might be: imported soybean oil (40\%), domestic sunflower (10\%), imported palm oil (25\%) and rapeseed (25\%): (5\% domestic and 95\% imported) [17].

It is noted that domestic raw materials for biofuel production in Spain amounts to $22.5 \%$ (10\% sunflower and $5 \%$ of the $25 \%$ of rapeseed). Spain imports $77.5 \%$ of these raw materials.

Hence, it is noted that biofuels might reduce oil dependence, but Spain is nowadays importing most of the raw materials to produce biofuels and most of them are from countries that do not belong to the European Union.

Hydrogen could reduce this dependence because it could be obtained from water via electrolysis. In this case it is necessary to analyze the origin of the energy that is required to decompose the water molecule.

\subsection{Price stabilization}

Petroleum prices are expected to be volatile and to increase continuously over time. The Middle East was the source of crude oil spikes in 1973, 1979, and 1990 [15]. Furthermore, both the Chinese and Indian economies are growing fast, increasing global energy demand and petroleum prices. For example, China switched from being a net exporter of petroleum to a net importer in 1993, and today is building more complex refineries that can process sour crude oil (high sulfur content) from the Middle East [18]. Moreover, India imported approximately $74 \%$ of its petroleum needs in 2002 [19].

The current economic crisis has caused a sharp drop in oil prices (between July 2008 and February 2009 oil decreased by $58 \%$ ), but it is expected that the oil quota will rise again at the end of this crisis.

Biofuels and/or hydrogen could constrain the growth of petroleum prices, because biofuels are a backstop technology. If petroleum prices increase too rapidly, then society will substitute petroleum by biofuels. If biofuel prices increase too rapidly, then farmers expand their production of energy crops, causing a drop in price on the biofuel's market [20].

\subsection{Reducing GHG and other pollution emissions}

Biofuels may mitigate global warming by recycling carbon from the atmosphere and reducing most tail-pipe pollution from compression engines. However, tail-pipe emissions are variable and depend on the engine design, manufacturer, engine age, and engine maintenance. Biofuels contain little sulfur and no mercury. Therefore, sulfur dioxide and mercury emissions decrease when biofuels are blended with diesel and gasoline $[8,10,12,21]$.

Biodiesel and ethanol are oxygenates while diesel fuel and gasoline contain almost zero oxygen. Pure biodiesel contains 10 $12 \%$ oxygen on a weight basis $[8,12,21]$ and the ethanol contains $35 \%$ oxygen [22]. The presence of oxygen allows more complete combustion, which reduces emissions from hydrocarbons (HC), carbon monoxide (CO), and particulate matter (PM). Unfortunately, in the case of both fuels, the higher oxygen content increases $\mathrm{NO}_{x}$ emissions $[8-10,12,21]$.

Table 4 shows emissions of $\mathrm{CO}_{2}$ from fossil fuels and biofuels for Otto and Diesel engines.

$\mathrm{CO}_{2}$ emissions per unit of energy are similar in all cases. To evaluate and compare them properly, it is necessary to take into account the whole life cycle of the fuels: from the origin of the raw materials to the combustion in an engine. In the case of biofuels, there is some controversy on this point as there are authors who maintain that the energy balance is negative [23] while others say that it is positive [24].

In the case of biofuels, the authors of this report suggest taking into account the nature of the production of raw material. This is because it is not the same to create new crops than to use crop surpluses or to use waste when evaluating the mass balance and energy. In the first case the absorption of $\mathrm{CO}_{2}$ in the mass balance must be taken into account but not in the second and third cases.

When hydrogen reacts with oxygen, there are no $\mathrm{CO}_{2}$ emissions. The result is water and the generation of heat (it is an exothermic reaction). The only byproduct is produced by some air-hydrogen proportions and is the emission of $\mathrm{NO}_{x}$.

Producing hydrogen demands energy and in order to consider the whole life cycle, it is necessary to take into account the $\mathrm{CO}_{2}$ emissions when generating this energy. These emissions depend on the way this energy is produced.

\subsection{Additional source of income}

A large biofuel industry could increase prices and income for the agricultural sector [10]. Agricultural producers are subject to low commodity prices, largely inelastic demand, and many unpredictable events. The unpredictable events originate from the weather, biological problems like destructive viruses, fungi, or insects, volatile commodity prices and yields, business cycles causing shifting demand for agricultural products over time, and unstable export demand.

Table 4

Fossil fuel and biofuel emissions for Otto and Diesel type engines.

\begin{tabular}{|c|c|c|c|c|}
\hline & Gasoline 95 & Gasoil & E85 & Biodiesel \\
\hline $\mathrm{CO}_{2}$ in terms of volume & $2356 \mathrm{~g} / \mathrm{L}$ & $2744 \mathrm{~g} / \mathrm{L}$ & $1644 \mathrm{~g} / \mathrm{L}$ & $2514 \mathrm{~g} / \mathrm{L}$ \\
\hline $\mathrm{CO}_{2}$ in terms of energy & $73.15 \mathrm{~g} / \mathrm{MJ}$ & $74.31 \mathrm{~g} / \mathrm{MJ}$ & $71.74 \mathrm{~g} / \mathrm{MJ}$ & $75.73 \mathrm{~g} / \mathrm{MJ}$ \\
\hline
\end{tabular}


The low commodity prices and unpredictable events cause farmers' income and wealth accumulation to be low and variable [25]. However, a large energy industry provides an elastic demand for biofuels and if the biofuel industry is large this in turn creates a large demand for agricultural feedstocks, increasing agricultural prices and income. Furthermore, biofuels could help farmers hedge against agricultural fluctuating prices, as a farmer could grow a variety of crops, and still be able to supply renewable energy.

A large biofuel industry has other benefits, which include reductions in government subsidies to farmers [22], movement of dormant agricultural land into production [11], and increases in rural employment [11]. For instance, farmers hire more workers to grow more energy crops and biorefineries hire more workers to convert energy crops into biofuel. The biorefineries are expected to be located close to the agricultural producers, because hauling costs increase exponentially the further the feedstocks are transported. Finally, the biofuel industry is capital intensive, widening the tax base for rural governments [11].

This advantage does not appear in the case of hydrogen if it is obtained by electrolysis of seawater.

\section{Actions to promote the use of alternative fuels}

\subsection{Actions for the development of biofuels}

\subsubsection{Directive 2003/30/EC of the European Union}

In 2003 the European Union (EU) Directive 2003/30/EC [1] was developed with the aim of promoting the use of biofuels as a substitute for diesel or gasoline among European Union countries as well as to contribute to fulfilling the commitments on climate change, security of supply in environmentally friendly conditions and the promotion of renewable energy sources.

In order to achieve these goals, the directive forces all EU members to ensure that before December 31 of 2010 , at least $5.75 \%$ of all gasoline and diesel fuels sold for transport purposes are biofuels. European Union countries have social and economic characteristics unique to themselves. The energy dependence from foreign sources, the features of the agricultural sector or the degree of industrialization varies greatly from one country to another. In this context, it is questionable whether the obligation imposed by this directive applies to achieve uniform and/or identical goals in each of the countries involved and whether the actions of the various governments are also aligned with these goals.

For instance, 72,483 thousand tons of oil were consumed in Spain in 2008 . $44.32 \%$ (32,126 tons) were to produce automotive fuels (gasoline and diesel fuel). Thus, the goal for Spain is to replace the equivalent to 1847 thousand tons of oil (5.75\%).

Being a compulsory directive for all EU members, individual EU governments are encouraging actions to comply with it. It is however important to note that the actions of governments are perhaps aimed at fulfilling the obligations fixed by the Directive but not at fulfilling its own unique objectives.

The European Union is made up of 27 countries that have specific social and economic characteristics. Energy dependence or degree of industrialization varies greatly from one country to another. In this context, it is necessary to consider:

- If the obligation imposed by the directive is inadequate for achieving the goals of the directive in each of the countries.

- If government actions are aligned with the objectives set by the directive. That is to say, if government actions are aligned with the objectives.

The authors of this report made a case study for the use of citrus waste in a newly built plant in L'Alcudia, Valencia (Spain) [2], showing that this consistency is not always achieved.

\subsubsection{Tax incentives for biofuels}

Taxes are an artificial way to alter the natural market of supply and demand [26]. This is because if the offer sets a price target that is capable of matching the demand, tax makes the prices increase and the offer shrink. Hence, the match point offer-demand is for a point that increases the price and diminishes the quantity. The fossil fuels are highly taxed: for gasoline and gasoil, almost half of the prices are taxes.

Some European countries are supporting biofuels by taxing them much less than fossil fuels. For instance, in Spain, biofuels do not bear the hydrocarbons special tax that is supported by fossil fuels. Law 53/2002 of 30 December on fiscal, administrative and social order adds a new Article 50a in order to make a total exemption from taxation for biofuels (ethanol, methanol and vegetable oil) until 2012. This exemption is made with the aim of "promoting the use of energy and environmental benefits of fuels from agricultural sources, compensating their higher production costs".

\subsection{Actions for the promotion of hydrogen as fuel}

Hydrogen is only considered a biofuel if it is generated from biomass feedstock. The ITC/2877/2008 order of October 9 provides a way for promoting biofuels and other renewable fuels for transportation purposes.

\section{Use of hydrogen as automotive fuel}

Hydrogen can be used as an automotive fuel in two ways:

(1) As a fuel for internal combustion engines. In this case, hydrogen is similar to gasoline and diesel fuel and the maximum efficiency on the lower heating value (LHV) is $27 \%$.

(2) As a fuel for fuel cells. In this case the efficiency is close to $60 \%$ on the LHV for an alkaline fuel cell-type. There is also another advantage: if the vehicle does not require energy, no fuel is consumed (i.e. in traffic jams or stopped at a traffic light). A vehicle with an internal combustion engine consumes fuel when idling and its performance is equal to zero.

\section{Advantages and disadvantages of hydrogen as fuel}

Hydrogen has features that may be considered advantageous over the use of fossil fuels and biofuels:

- It is a stable element. It is non-corrosive.

- It has a high LHV per mass unit. This feature means low weight of fuel in canisters. Hydrogen is three times lighter than gasoline or diesel fuel per unit of mass for the same energy contained in the LHV.

- It has a high availability: hydrogen may be produced from different raw materials.

Combustion "clean." The reaction of hydrogen with oxygen produces only water and heat. But, due to the presence of nitrogen in the air, certain hydrogen-air mixtures produce oxides of nitrogen $\left(\mathrm{NO}_{x}\right)$.

- If hydrogen is produced by electrolysis, the environmental impact caused by oil extraction is eliminated.

- Hydrogen may be used in fuel cells and internal combustion engines. In case it is used in fuel cells, the following features appeared:

a. High performance: to convert fuel into energy through an electrochemical reaction is more efficient than burning it in an engine. The process can achieve efficiencies ranging from $30 \%$ to $90 \%$. If hydrogen is used in an internal combustion engine, first it 
is converted into heat and later into mechanical energy so efficiency is limited by Carnot's law. The last process means friction and other losses causing a reduction in efficiency. Fuel cells are not limited by Carnot's law and only limitations in the use of energy and materials limit the performance.

b. Silent: with no moving parts, it has been estimated that the noise level of a fuel cell is $55 \mathrm{~dB}$ at $30 \mathrm{~m}$. Thus, this technology is very adequate for urban purposes.

c. Low temperatures and pressures of operation: fuel cells operate between 80 and $1000^{\circ} \mathrm{C}$. The temperature inside the internal combustion engine can go over $2300^{\circ} \mathrm{C}$.

d. Cogeneration capacity: it is possible to use the waste heat generated by the electrochemical reaction on the fuel cell for other purposes such as the heating system of the vehicle. When this capacity is used, the efficiency can reach $90 \%$.

e. Simplicity: fuel cells have no moving parts, allowing a simpler design, greater reliability and functionality being less prone to breakdowns.

f. Energy security: the way to increase the output of a fuel cell is to introduce more fuel. In addition, a fuel cell never runs down as long as there is fuel to produce electricity. When a battery runs out it has to go through a long and inconvenient recharge time to replace the spent energy.

On the other hand, some features may be considered disadvantages:

- It has low LHV per unit of volume. This means using high volume and heavy canisters.

- Transportation and storage are expensive and complex.

- Hydrogen is a "secondary" fuel because it requires energy to be produced just like biofuels (biodiesel and ethanol) do. Hydrogen does not exist in the environment as oil does.

- Hydrogen cannot be used directly in vehicles. Most vehicles are prepared to use biofuels, but in order to use hydrogen the vehicle needs to be adapted and this means a higher cost.

The production of some components requires a high cost due to the absence of a large scale market. It is estimated that a fuel cell car is $30 \%$ more expensive than a similar gasoline or diesel vehicle.

- As an emerging technology, there are certain problems that have not yet been resolved and that affect functioning, especially in the operating life. Obviously this has an impact on the commercialization.

- There is a low demand for fuel cells. Hence, the unit price cannot compete with conventional technologies. It is expected that prices will be lower as demand increases.

Fuel cells are sensitive to catalytic poisons. The electrodes incorporate catalysts used to increase the performance of electrochemical reactions. The contact of these substances with known catalytic poisons causes irreversible deactivation of the fuel cell. Nowadays the replacement of these catalysts by more durable materials is being considered.

\section{Analysis of hydrogen as automotive fuel}

\subsection{Variable chosen for the economic comparison}

The best variable for the economic comparison is the energy price contained in the LHV. Gasoline and gasoil figures are shown in Table 5.

Table 6 shows the maximum and minimum oil quotation between July 2003 and March 2009. Oil is quoted in dollars. This means that is necessary to take into account the rate of euro-dollar change at the time of the transaction. It also means that the maximum and minimum quotations do not have to match in time.
Table 5

LHV per mass and volume and density of gasoline and gasoil

\begin{tabular}{lcc}
\hline & Gasoline 95 & Gasoil \\
\hline LHV (per mass) & $43.53 \mathrm{MJ} / \mathrm{kg}$ & $42.69 \mathrm{MJ} / \mathrm{kg}$ \\
Density & $0.740 \mathrm{~kg} / \mathrm{L}$ & $0.865 \mathrm{~kg} / \mathrm{L}$ \\
LHV (per volume) & $32.21 \mathrm{MJ} / \mathrm{L}$ & $36.93 \mathrm{MJ} / \mathrm{L}$ \\
\hline Source: [27]. & &
\end{tabular}

Table 6

Maximum and minimum oil quotes between July 2003 and March 2009.

\begin{tabular}{lcl}
\hline Maximum Oil price (Brent) & $\$ 133.19(\mathrm{Jul} / 08)$ & $85.14 €(\mathrm{Jun} / 08)$ \\
Minimum Oil price (Brent) & $\$ 40.44(\mathrm{Dec} / 08)$ & $24.31 €(\mathrm{Dec} / 03)$ \\
\hline
\end{tabular}

Source: [28].

Table 7

Maximum and minimum costs for gasoline and gasoil between July 2003 and March 2009.

\begin{tabular}{lrr}
\hline & Gasoline 95 & \multicolumn{1}{l}{ Gasoil } \\
\hline Minimum cost without taxes (Jul/08) & $21.18 € / \mathrm{GJ}$ & $22.28 € / \mathrm{GJ}$ \\
Maximum cost without taxes $(\mathrm{Dec} / 03)$ & $8.97 € / \mathrm{GJ}$ & $7.75 € / \mathrm{GJ}$ \\
\hline Source: $[28]$ & &
\end{tabular}

Table 7 shows maximum and minimum costs for gasoline and gasoil between July 2003 and March 2009. These values do not match in time with the maximum and minimum oil quotation.

An alternative fuel or biofuel should have equivalent or lower costs than gasoline and gasoil to be profitable. In this report, authors consider:

An alternative fuel (hydrogen or biofuel) will always be competitive if its price per unit of energy is lower than the minimum price than gasoline and gasoil reached between July 2003 and March 2009. This value is $7.75 € / G$ J and is marked as "lower limit of profitability."

- An alternative fuel (hydrogen or biofuel) will not always be competitive if its price per unit of energy is higher than the maximum price than gasoline and gasoil reached between July 2003 and March 2009. This value is $22.28 € / G$ J and is marked as "higher limit of profitability."

- There are uncertainties about the competitiveness of an alternative fuel if its price per unit of energy is between the lower and the higher limit of profitability (from 7.75 to $22.28 €(\mathrm{GJ})$.

5.2. Key to evaluate the economic competitiveness of biofuels, the price of oil

A statistical analysis is to be made to evaluate if there is a linear relationship between oil quotations and gasoline and gasoil costs. Oil is quoted and paid in dollars. Hence, in order to analyze a typical European case, the Spanish one, it is necessary to know:

- Oil quoted price in U.S. dollars.

- The average exchange rate of the month.

- The average price of gasoline and gasoil for that month.

Taking data from [28], Fig. 1 is obtained.

For gasoline, $R^{2}$ value is 0.9419 and the linear correlation coefficient is 0.9705 . For gasoil, $R^{2}$ value is 0.9346 and the linear correlation coefficient is 0.9667 . This figures show that gasoline and gasoil costs are linearly related to the oil quotation.

For an alternative fuel intended to replace gasoline and gasoil, the lower the oil quotation, the higher the competitiveness of the 


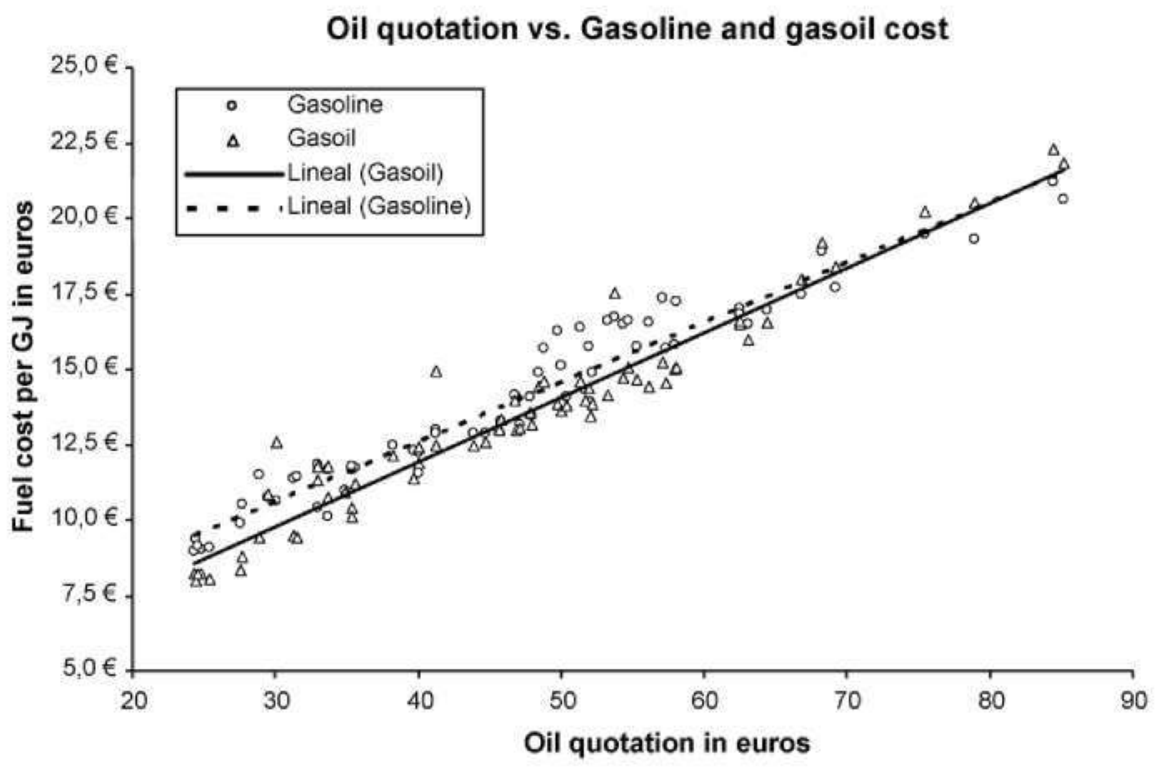

Fig. 1. Oil quotation vs. gasoline and gasoil costs.Source: [28]/Authors.

alternative fuel and vice versa. This relation is to be considered as linear.

\subsection{Assumptions for the technical and economic analysis of hydrogen}

Fig. 2 shows a scheme for the proposed cycle of hydrogen production by the electrolysis of seawater.

The assumptions made for the analysis are the following:

- Hydrogen is obtained by electrolysis of seawater. Hence, the plant is to be located close to the sea.

- The power plant is to be located close to the electrolysis plant in order to minimize the power lost due to transportation.

- Process byproducts will not be taken into account. Oxygen and salt have an economic value that will not be consider in this analysis.

- There will be three variables:

a. The cost of the energy generated at the power plant.

b. The efficiency of the process to obtain hydrogen; the percentage of the energy generated at the power plant that reaches the electrolysis plant.

c. The economic efficiency of the process to obtain hydrogen.

\subsection{Water decomposition energy cost}

The enthalpy of formation of water is $285.49 \mathrm{~kJ} / \mathrm{mol}$. This means that decomposing $18 \mathrm{~g}$ of water requires $285.49 \mathrm{~kJ}$ or for our purpose to obtain $2 \mathrm{~g}$ of hydrogen, $285.49 \mathrm{~kJ}$ are required. Thus, $142,747 \mathrm{~kJ}$ of electricity are required to obtain $1 \mathrm{~kg}$ of hydrogen.

Hydrogen LHV is $120,011 \mathrm{~kJ} / \mathrm{kg}$. This means that the amount of energy required to obtain hydrogen is larger than the energy that contains hydrogen in its LHV.

Formula (1) shows the cost to obtain a unit of energy from hydrogen. This cost depends on the efficiency of the process and the unit cost of the energy generated at the power plant.

$P(€ / \mathrm{GJ})=\frac{P_{e}(€ / \mathrm{kWh})}{\eta_{p}} \frac{1000}{3.6}(\mathrm{kWh} / \mathrm{GJ}) \frac{D(\mathrm{MJ} / \mathrm{kg})}{\mathrm{LHV}_{\text {Hydrogen }}(\mathrm{MJ} / \mathrm{kg})}$

where

- $P$ is the cost of hydrogen obtained in the process ( $€ / G \mathrm{~J}$ ).

- $P_{e}$ is the cost of the electricity generated at the power plant $(€$ / $\mathrm{kWh}$ ).

- $\eta_{p}$ is the efficiency of the process.

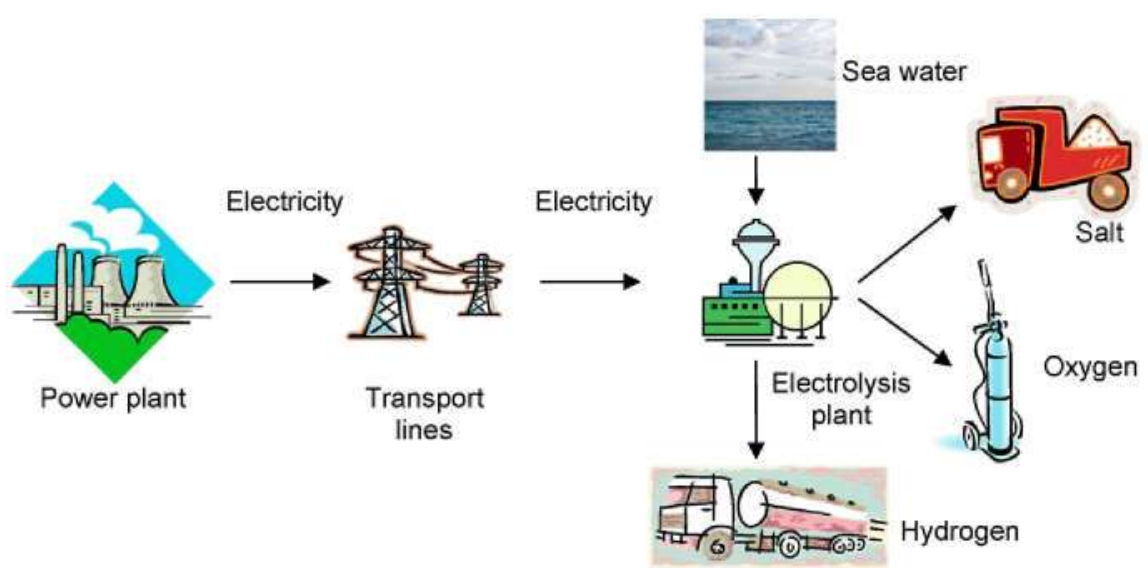

Fig. 2. Scheme for the production of hydrogen via electrolysis of sea water-Source: Authors. 
Table 8

Production cost per unit of energy generated in the power plant (including externalities).

\begin{tabular}{ll}
\hline Coal & $0.070 € / \mathrm{kWh}$ \\
Fuel oil & $0.060 € / \mathrm{kWh}$ \\
Natural gas & $0.039 € / \mathrm{kWh}$ \\
Nuclear & $0.035 € / \mathrm{kWh}$ \\
Hydraulic & $0.047 € / \mathrm{kWh}$ \\
Wind & $0.062 € / \mathrm{kWh}$ \\
\hline Source: $[29]$. &
\end{tabular}

Table 9

Production cost of hydrogen per unit of energy on the LHV ( $€ / M J)$.

\begin{tabular}{llllllll}
\hline \multirow{2}{*}{ Type } & \multicolumn{2}{l}{ Efficiency } \\
\cline { 2 - 8 } & $90 \%$ & $80 \%$ & $70 \%$ & $60 \%$ & $50 \%$ & $40 \%$ & $30 \%$ \\
\hline Coal & $\mathbf{2 5 . 7 0}$ & 28.91 & 33.04 & 38.55 & 46.26 & 57.82 & 77.09 \\
Fuel oil & $\mathbf{2 2 . 0 3}$ & 24.78 & 28.32 & 33.04 & 39.65 & $49.56 €$ & 66.08 \\
Natural gas & $\mathbf{1 4 . 3 2}$ & $\mathbf{1 6 . 1 1}$ & $\mathbf{1 8 . 4 1}$ & $\mathbf{2 1 . 4 8}$ & 25.77 & 32.21 & 42.95 \\
Nuclear & $\mathbf{1 2 . 8 5}$ & $\mathbf{1 4 . 4 6}$ & $\mathbf{1 6 . 5 2}$ & $\mathbf{1 9 . 2 7}$ & 23.13 & 28.91 & 38.55 \\
Hydraulic & $\mathbf{1 7 . 2 5}$ & $\mathbf{1 9 . 4 1}$ & $\mathbf{2 2 . 1 8}$ & $\mathbf{2 5 . 8 8}$ & 31.06 & 38.82 & 51.76 \\
Wind & 22.76 & 25.61 & 29.26 & 34.14 & 40.97 & 51.21 & 68.28 \\
\hline
\end{tabular}

$D$ is the energy to decompose the water molecule $(\mathrm{MJ} / \mathrm{kg}$ of hydrogen).

- $\mathrm{LHV}_{\mathrm{Hydrogen}}$ is the LHV of hydrogen ( $\mathrm{MJ} / \mathrm{kg}$ of hydrogen).

The estimated costs of power generation, including externalities, are shown in Table 8.

The hydrogen cost per energy unit can be calculated using the formula (1). Table 9 shows the results for different efficiency values and for different types of power plants.

Values in bold show, for different types of power plants, the values for efficiency which may be competitive with gasoline and gasoil. Fig. 3 shows these results graphically.

\section{Results}

The results of the comparison are now shown.

\subsection{If hydrogen is used in an internal combustion engine}

The efficiency of hydrogen on the LHV is similar to the efficiency obtained with gasoline or gasoil.
According to the authors' criteria, all points below the line marked as lower profitability value in Fig. 3 are always competitive. There are no values below this line.

However, there are values between the lower and the higher profitability values. This means that hydrogen production is cost effective for certain types of power plants and efficiency values.

As shown in Fig. 3:

- The higher the efficiency the higher the competitiveness and vice versa.

- The lower the price of the energy produced at the power plant the higher the competitiveness and vice versa.

\subsection{If hydrogen is used in an alkaline fuel cell}

The efficiency on the LHV is significantly different when hydrogen is to be used in an alkaline fuel cell. These are the reasons:

Fuel cell efficiency is $60 \%$ when the efficiency of an internal combustion engine is much lower (35\% maximum).

- The internal combustion engine consumes fuel when idling and the vehicle does not move (in a traffic jam or when stopped at a traffic light). In those cases, a fuel cell has a minimum consumption. With this data, it is estimated that the global efficiency of a fuel cell is twice the efficiency of an internal combustion engine.

Thus, lower and higher profitability values might be multiplied by 2 when hydrogen is used in fuel cells. The lower profitability value is now $15.5 € / G$ J and the higher profitability value is now $44.56 € / G J$. This means that when hydrogen is used in fuel cells, there is a larger range of values for efficiency and primary energy cost in which it becomes economically viable.

Oil savings (in ktoe) are calculated using formula (2).

$$
\begin{aligned}
E_{H}(\mathrm{ktoe})= & E(\text { MW year }) \cdot 325(\text { day } / \text { year }) \cdot 24(\text { hour } / \text { day }) \cdot \eta_{p} \\
& \cdot 1000(\mathrm{kWh} / \mathrm{MWh}) \cdot 86 \times 10^{-9}(\mathrm{ktoe} / \mathrm{kWh}) \\
& \cdot \frac{D(\mathrm{MJ} / \mathrm{kg})}{\mathrm{LHV}_{\text {Hydrogen }}(\mathrm{MJ} / \mathrm{kg})}
\end{aligned}
$$

where

- $E_{H}$ is the energy contained in the obtained hydrogen (ktoe).

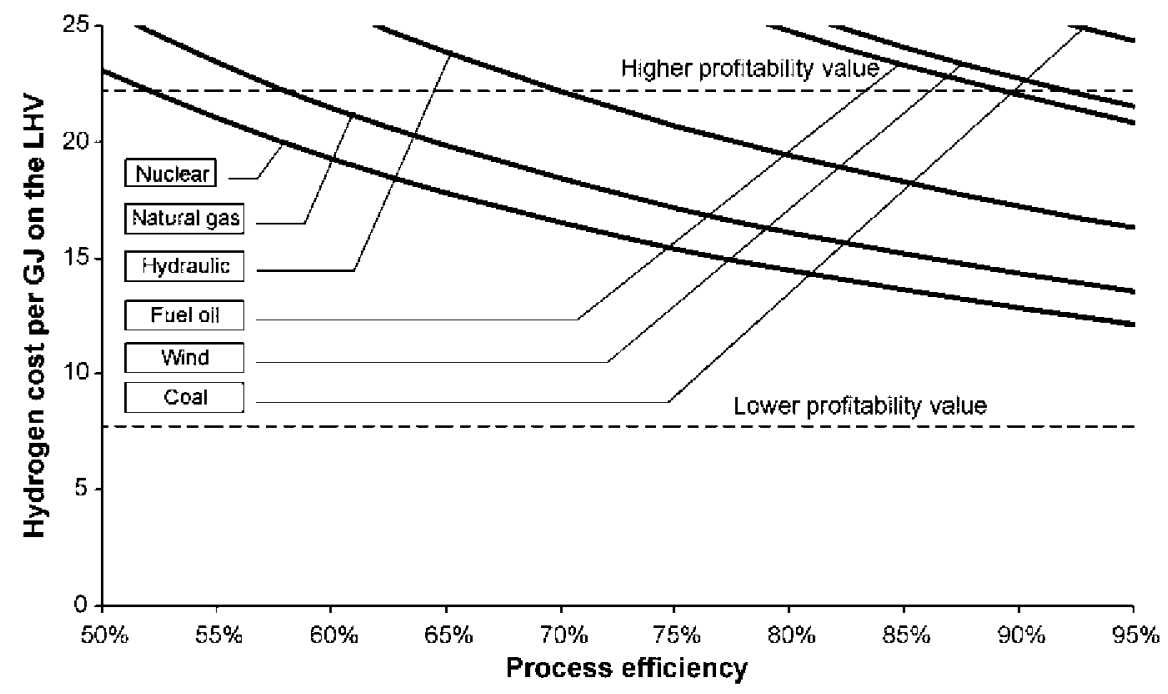

Fig. 3. Production cost per unit of energy generated at the power plant as a function of the type of power plant and the efficiency of the process.Source: Authors. 
Table 10

Hydrogen (in ktoe on the LHV) obtained for different values of efficiency and annual energy generated by the power plant if hydrogen is to be used in internal combustion engines.

\begin{tabular}{|c|c|c|c|c|c|c|c|}
\hline \multirow[t]{2}{*}{ Annual energy (MWyear) } & \multicolumn{7}{|c|}{ Efficiency over the energy supplied by the power plant } \\
\hline & $90 \%$ & $80 \%$ & $70 \%$ & $60 \%$ & $50 \%$ & $40 \%$ & $30 \%$ \\
\hline 100 & 57 & 51 & 44 & 38 & 32 & 25 & 19 \\
\hline 500 & 285 & 253 & 222 & 190 & 158 & 127 & 95 \\
\hline 1000 & 570 & 507 & 443 & 380 & 317 & 253 & 190 \\
\hline 1500 & 855 & 760 & 665 & 570 & 475 & 380 & 285 \\
\hline
\end{tabular}

Source: Authors.

Table 11

Percentage of savings on the total gasoline and gasoil consumption in Spain for 2008 for different values of efficiency and annual energy generated by the power plant if hydrogen is to be used in internal combustion engines.

\begin{tabular}{|c|c|c|c|c|c|c|c|}
\hline \multirow[t]{2}{*}{ Annual energy (MWyear) } & \multicolumn{7}{|c|}{ Efficiency over the energy supplied by the power plant } \\
\hline & $90 \%$ & $80 \%$ & $70 \%$ & $60 \%$ & $50 \%$ & $40 \%$ & $30 \%$ \\
\hline 100 & $0.18 \%$ & $0.16 \%$ & $0.14 \%$ & $0.12 \%$ & $0.10 \%$ & $0.08 \%$ & $0.06 \%$ \\
\hline 500 & $0.89 \%$ & $0.79 \%$ & $0.69 \%$ & $0.59 \%$ & $0.49 \%$ & $0.39 \%$ & $0.30 \%$ \\
\hline 1000 & $1.77 \%$ & $1.58 \%$ & $1.38 \%$ & $1.18 \%$ & $0.99 \%$ & $0.79 \%$ & $0.59 \%$ \\
\hline 1500 & $2.66 \%$ & $2.37 \%$ & $2.07 \%$ & $1.77 \%$ & $1.48 \%$ & $1.18 \%$ & $0.89 \%$ \\
\hline
\end{tabular}

Source: Authors.

- $E$ is the electric energy generated at the power plant (MW year).

- $\eta_{p}$ is the efficiency of the process.

- $D$ is the energy to decompose the water molecule $(\mathrm{MJ} / \mathrm{kg}$ of hydrogen).

- LHV $\mathrm{Hydrogen}_{\text {is }}$ the LHV of hydrogen (MJ/kg of hydrogen).

Table 10 shows the results for different values of efficiency and annual energy.

For instance, in Spain 32,126 ktoe of gasoline and gasoil were consumed in 2008 [30]. Table 11 shows the percentage of savings in relation with the efficiency and the energy generated by the power plant.

If hydrogen is used in fuel cells, the efficiency on the LHV is twice. Thus, figures shown in Tables 10 and 11 are multiplied by two.

Table 12

$\mathrm{CO}_{2}$ emissions per unit of energy generated at the power plant [31].

\begin{tabular}{lcc}
\hline & \multicolumn{2}{c}{$\mathrm{CO}_{2}$ emissions } \\
\cline { 2 - 3 } & $\mathrm{g} / \mathrm{kWh}$ & $\mathrm{g} / \mathrm{MJ}$ \\
\hline Coal & 960 & 3456 \\
Fuel Oil & 720 & 2592 \\
Natural Gas & 480 & 1728 \\
Nuclear & 6 & 21.6 \\
Hydraulic & 4 & 14.4 \\
Wind & $3-22$ & $10.8-79.2$ \\
Photovoltaic & $50-150$ & $180-540$ \\
\hline
\end{tabular}

\section{3. $\mathrm{CO}_{2}$ emissions}

Hydrogen production process efficiency does not depend on the power plant type. GHG and the cost of energy depend on the power plant type. $\mathrm{CO}_{2}$ emissions for different power plants are shown in Table 12 .

$\mathrm{CO}_{2}$ emissions per unit of energy on the LHV of hydrogen can be calculated for different values of the process efficiency and the $\mathrm{CO}_{2}$ emissions of the power plant. Formula (3) shows how it is calculated.

$G(\mathrm{~g} / \mathrm{MJ})=\frac{G_{e}(\mathrm{~g} / \mathrm{MJ})}{\eta_{p}} \cdot \frac{D(\mathrm{MJ} / \mathrm{kg})}{\mathrm{LHV}_{\text {Hydrogen }}(\mathrm{MJ} / \mathrm{kg})}$

where

- $G$ are $\mathrm{CO}_{2}$ emissions per unit of energy on the LHV of hydrogen $(\mathrm{g} /$ $\mathrm{MJ})$.

- $G_{e}$ are $\mathrm{CO}_{2}$ emissions per unit of energy generated at the power plant (g/MJ).

- $\eta_{p}$ is the efficiency of the process.

- $D$ is the energy to break the water molecule ( $\mathrm{MJ} / \mathrm{kg}$ of hydrogen).

- LHV $V_{\text {Hydrogen }}$ is the LHV of hydrogen (MJ/kg of hydrogen).

Results for different types of power plants and efficiency values of the process are shown in Table 13.

Gasoline generates $73.15 \mathrm{~g} / \mathrm{MJ}$ when it is burned and gasoil generates $74.71 \mathrm{~g} / \mathrm{MJ}$. Figures in bold type in Table 13 show efficiency values and types of power plants that have less $\mathrm{CO}_{2}$

Table 13

$\mathrm{CO}_{2}$ emissions per unit of energy on the LHV of hydrogen ( $\mathrm{g} / \mathrm{MJ}$ ).

\begin{tabular}{|c|c|c|c|c|c|c|c|}
\hline \multirow[t]{2}{*}{ Type } & \multicolumn{7}{|c|}{ Process efficiency } \\
\hline & $90 \%$ & $80 \%$ & $70 \%$ & $60 \%$ & $50 \%$ & $40 \%$ & $30 \%$ \\
\hline Coal & 4567 & 5138 & 5872 & 6851 & 8221 & 10,277 & 13,702 \\
\hline Fuel Oil & 3426 & 3854 & 4404 & 5138 & 6166 & 7,708 & 10,277 \\
\hline Natural gas & 2284 & 2569 & 2936 & 3426 & 4111 & 5,138 & 6,851 \\
\hline Nuclear & 29 & 32 & 37 & 43 & 51 & 64 & 86 \\
\hline Hydraulic & 19 & 21 & 24 & 29 & 34 & 43 & 57 \\
\hline Wind & 14-103 & $16-117$ & 18-132 & 21-154 & 26-191 & $32-235$ & 43-315 \\
\hline Photovoltaic & $238-714$ & $268-804$ & $306-918$ & $357-1071$ & $428-1284$ & $535-1,605$ & $714-2,142$ \\
\hline
\end{tabular}

Source: Authors. 
emissions than gasoline and gasoil. Table 13 leads to the conclusion that:

- The use of fossil fuels (coal, fuel oil and natural gas) or photovoltaic energy as primary energy to perform water electrolysis to obtain hydrogen always produces more $\mathrm{CO}_{2}$ emissions than the use of gasoline or gasoil in an internal combustion engine.

- The use of nuclear power plants, hydraulic plants or wind generators to perform water electrolysis to obtain hydrogen generates less $\mathrm{CO}_{2}$ emissions than the use of gasoline or gasoil in an internal combustion engine.

- The use of hydrogen in fuel cells instead of its use in internal combustion engines reduces by one half the $\mathrm{CO}_{2}$ emissions due to the higher efficiency of fuel cells in comparison to internal combustion engines.

\section{Conclusions}

As it has been noted, the variable to compare alternative fuels to gasoline and gasoil is the price per unit of energy on the LHV.

It has been shown that the production and the use of biofuels may change the external dependence of the countries: instead of depending on oil imports.

It has been demonstrated that gasoline and diesel costs are related in a linear way to oil quotation. The higher the oil quotation the higher the competitiveness of the alternative fuels and vice versa.

Nowadays, due to state of the art technology and costs, forcing the production and consumption of biofuels is not cost effective. This is because, from an economic point of view, it is very difficult for biofuels to compete with mineral fuels. Mineral fuels are extracted from geological formations, processed and delivered to consumers while biofuels require the processing of the raw materials which is both complex and expensive in terms of energy and economic cost.

In combustion terms, the amount of $\mathrm{CO}_{2}$ generated by biofuels is similar to that of fossil fuels. Furthermore, the process of getting fuel from plants requires energy (heat and power) and in order to obtain this energy $\mathrm{CO}_{2}$ is generated.

Raw materials for biofuels have absorbed $\mathrm{CO}_{2}$ before it reaches the processing plant but this absorption should not always be taken into account in the mass and energy balances.

It is important to point out that in certain European countries like Spain (which has a strong primary sector), a high percentage of the raw materials used to produce biofuels is imported. This calls into question the objective of European Directive 2003/30/EC for the reduction of the external energy dependence because this dependence is replaced by the dependence on the raw materials to produce biofuels.

Hydrogen may be an alternative to gasoline, gasoil and biofuels for the automotive sector. Hydrogen can be used in internal combustion engines or in fuel cells. An analysis of a model to produce hydrogen via electrolysis of sea water has been performed.

The results of this analysis show that, depending on the energy cost and the process efficiency, there is a wide range of possibilities in which the generation of hydrogen by electrolysis is cost effective without requiring subsidies or tax exemptions.

Finally, it has been shown that when using wind generators or hydraulic power plants with an overall process efficiency higher than $30 \%$ or a nuclear power plant with an efficiency greater than $40 \%$, then the process of producing hydrogen to be used in internal combustion engines is cost effective and generates less $\mathrm{CO}_{2}$ emissions than the use of gasoline or gasoil.

\section{References}

[1] 2003/30/EC Directive of the European Parliament and the Council - 8th May 2003. On the promotion of the use of biofuels or other renewable fuels for transport.

[2] Sobrino FH, Monroy CR. Critical analysis of the European Union directive which regulates the use of biofuels: An approach to the Spanish case. Renewable \& Sustainable Energy Reviews 2009. doi: 10.1016/j.rser.2009.05.003.

[3] http://www.ine.es/jaxi/tabla.do?path $=/$ t04/a082/e01/10/\&file=01001 $. p x \& t y p e=$ pcaxis\&L=0 [last access: 2-2-09]

[4] Libro de la Energía en España. Ministerio de Industria, Turismo y Comercio. http://www.mityc.es/energia/es-ES/Servicios1/Destacados/LaEnerg\%C3\%A DaenEspa\%C3\%B 1a2007.pdf [last access: 25-6-09]

[5] http://www.belt.es/noticiasmdb/HOME2 noticias.asp?id=342. enero de 2006 [last access: 5-5-09]

[6] http://www.ine.es/jaxi/tabla.do?path=/t04/a082/a1998/10/\&file=e01002.px\&type=pcaxis\&L=0 [last access: 5-5-09]

[7] Gnansounou E, Dauriat A, Wyman CE. Refining sweet sorghum to ethanol and sugar: economic trade-offs in the context of North China. Bioresource Technology 2005;96(June (9)):985-1002.

[8] Fukuda H, Kondo A, Noda H. Review-biodiesel fuel production by transesterification of oils. Journal of Bioscience and Bioengineering 2001;92(5):405-16.

[9] Hewlett EM, Boswell BS, Erickson MV, Walter KM, Ferguson CD, Hart ML Sherwood PB. Commercial production of ethanol in the San Luis Valley, Colorado. Springfield, VA, US: Technical Information Center; July 1983.

[10] Sheehan J, Camobreco V, Duffield J, Graboski M, Shapouri H. An Overview of Biodiesel and Petroleum Diesel Life 2003/30/EC Directive of the European Parliament and the Council - 8th May 2003. On the promotion of the use of biofuels or other renewable fuels for transport; May 1998.

[11] Van Dyne DL, Weber JA, Braschler CH. Macroeconomic effects of a communitybased biodiesel production system. Bioresource Technology 1996;56(Apri (1)):1-6.

[12] Wang WG, Lyons DW, Clark NN, Gautam M. Emissions from nine heavy trucks fueled by diesel and biodiesel blend without engine modification. Environmental Science Technology 2000;34:933-9.

[13] http://www.ine.es/jaxi/tabla.do?path=/t04/a082/a1998/10/\&file=e03001.px\& type $=$ pcaxis $\& \mathrm{~L}=0$.

[14] Boletín Trimestral de Coyuntura Energética. Ministerio de Industria, Turismo y Comercio. http://www.mityc.es/energia/balances/Balances/Coyuntura Trimestral/2007/COY4T07.pdf [last access: 25-6-09].

[15] Lugar, Richard G, James R, Woolsey. The new petroleum. Foreign Affairs 1999;78(1):88-102.

[16] Canton A. Cooperativas agro-alimentarias 30-7-08. www.ccae.com; 2008 [last access: 20-5-09].

[17] Lechón Y, Helena C, de la Rua C, Lago C, lzquierdo L, Sáez R.M., et al. “Análisis de Ciclo de Vida de Combustibles Alternativos para el Transporte. Fase Il. Análisis de Ciclo de Vida Comparativo de Biodiésel y Diésel" Ciemat - Centro de publicaciones - Ministerio del medio ambiente; 2006 - http://publicaciones. administracion.es [Last access: 5-may-09]

[18] Wang H. China's impact on the World Crude-Oil Market. The Journal of Energy and Development 1995:19(1):81-96.

[19] Rao RD. Modelling optimal exploitation of petroleum resources in India. Resources Policy September-December 2002;28(3-4):133-44.

[20] Ray Szulczyk K. Market penetration of biodiesel and ethanol. Texas A\&M University; 2007.

[21] Barnwal BK, Sharma MP. Prospects of biodiesel production from vegetable oils in India. Renewable and Sustainable Energy Reviews 2005;9(August (4)):363-78

[22] Shapouri H, Duffield JA, Graboski MS. Estimating the net energy balance of corn ethanol. Washington, DC: U.S. Department of Agriculture, Economic Research Service, Agricultural Economic Report No. 721; July 1995.

[23] Pimentel D. Ethanol fuels: energy security, economics, and the environment. Journal of Agricultural and Environmental Ethics 1991;4:1-13.

[24] Lechón Y, Helena C, de la Rua C, Lago C, Izquierdo L, Sáez R.M., et al. Análisis de Ciclo de Vida de Combustibles Alternativos para el Transporte. Fase I. Análisi de Ciclo de Vida comparativo del etanol de cereales y de la gasolina. Ciemat. Centro de publicaciones. Ministerio del medio ambiente; 2005 http://publicaciones.administracion.es (access date: 5-may-09).

[25] Mishra AK, El-Osta HS, Morehart MJ, Johnson JD, Hopkins JW. Income, wealth, and the economic well-being of farm households. Washington, DC: U.S Department of Agriculture, Economic; July 2002.

[26] Allen F, Myers S, Brealey R. Principles of Corporate Finance, 8th ed., Boston: McGraw-Hill; 2005.

[27] Martín F, Sala V. Estudio comparativo entre los combustibles tradicionales y las nuevas tecnologías energéticas para la propulsión de vehículos destinados al transporte. Universitat Politècnica de Catalunya. Departament de Màquines 1 Motors Tèrmics: 2004.

[28] Informes mensuales de los precios de los carburantes. Ministerio de Industria, Turismo y Comercio. http://www.mityc.es/energia/petroleo/Precios/Informes/ InformesMensuales/Paginas/IndexInformesMensuales.aspx [last access 25-509].

[29] European Commission, ExternE Project. http://externe.jrc.ec.europa.eu/ [last access 25-5-09].

[30] Cores.es. http://www.cores.es/adjuntos/Consumos\%202007.xls [last access 26-5-09].

[31] Société Française d'Énergie Nucléaire. Revue Générale Nucléaire, 5, 9-10, 2007. 